\title{
Granulocyte-macrophage colony-stimulating factor, eosinophils and eosinophil cationic protein in subjects with and without mild, stable, atopic asthma
}

\author{
K.L. Woolley, E. Adelroth, M.J. Woolley, R. Ellis, M. Jordana, P.M. O'Byrne
}

Granulocyte-macrophage colony-stimulating factor, eosinophils and eosinophil cationic protein in subjects with and without mild, stable, atopic asthma. K.L. Woolley, E. Adelroth, M.J. Woolley, R. Ellis, M. Jordana, P.M. O'Byrne. CERS Journals Ltd 1994.

ABSTRACT: Increasing evidence implicates the eosinophil as an important effector cell in asthma, but little is known regarding its regulation in vivo. Granulocytemacrophage colony-stimulating factor (GM-CSF) has been shown to regulate eosinophil function in vitro. We investigated the in vivo role of eosinophils and GM-CSF in mild asthma.

We compared the number and function of eosinophils and the presence of GMCSF in blood, bronchoalveolar lavage (BAL) and biopsy tissue obtained from eight mild, stable, atopic asthmatics and $\mathbf{1 0}$ nonasthmatics, five of whom were atopic and five nonatopic.

Eosinophils were significantly increased in the blood, BAL and biopsy tissue from asthmatics. Activated eosinophils, assessed by immunostaining for the secreted form of eosinophil cationic protein (EG2), were also increased in asthmatic BAL cells and biopsy tissue. Significant increases in GM-CSF in BAL cells and biopsy tissue from asthmatics were also evident. Significant positive correlations existed between GMCSF in BAL and EG2, and GM-CSF in biopsy tissue and BAL and biopsy eosinophils. Airway responsiveness was also significantly positively correlated with eosinophil number and activation, and with GM-CSF.

These results demonstrate that there are increased numbers of activated eosinophils and GM-CSF is increased in patients with mild asthma. Furthermore, GM-CSF is correlated with eosinophil number and function in vivo and these indices are significantly correlated with airway function. These findings emphasize the importance of eosinophils, potentially regulated in vivo by GM-CSF, in contributing to the disordered airway function evident even in mild asthma.

Eur Respir J., 1994, 7, 1576-1584.
Asthma Research Group, Depts of Medicine and Pathology, McMaster University, Hamilton, Canada.

Correspondence: P.M. O'Byrne

Dept of Medicine

Rm 3U-1 Health Sciences Center

McMaster University

1200 Main St West

Hamilton

Ontario

Canada L8N $3 Z 5$

Keywords: Asthma

biopsy

cytokine

eosinophil

eosinophil cationic protein

granulocyte-macrophage colony-stimulating factor

Received: November 221993

Accepted after revision May 201994

KLW is the recipient of a Canadian Commonwealth Scholarship, MJ is the recipient of a MRC (Canada) Scholarship Award and $\mathrm{PMO}^{\mathrm{B}}$ is the recipient of a MRC (Canada) Scientist Award. The study was supported by the MRC (Canada) and a grant from Astra Pharma Inc. (Canada).
Airway inflammation is a characteristic feature of asthma, even in its mild form [1]. Whilst many different cell types may contribute to airway inflammation, increasing evidence suggests that the eosinophil may be particularly important. Mediators and proteins released from eosinophils are able to contract airway smooth muscle [2], damage the bronchial epithelium [3], and may induce airway hyperresponsiveness [4]. Increases in the number of eosinophils and levels of eosinophilderived proteins have been reported in the blood [5], sputum [6] and bronchoalveolar lavage (BAL) fluid [7] of patients with asthma. More recently, eosinophils have been examined in asthmatic bronchial tissue. Increases in the number and state of activation of eosinophils have been reported in some [8, 9] but not all [10, 11], studies. Examination of bronchial biopsies may be particularly important as eosinophils are predominantly tissue-dwelling cells, and inflammatory events occurring within the airway wall may be most relevant to the disordered airway function associated with asthma [12].

The increased number of eosinophils in asthmatic airways may reflect an increase in eosinophil recruitment and/or survival. The cytokine, granulocyte-macrophage colony-stimulating factor (GM-CSF), may be involved in these processes. In vitro, GM-CSF has been shown to be chemotactic for eosinophils [13], and can enhance the activation [14] and survival [15] of peripheral blood eosinophils. Limited information is available, however, concerning the presence and role of GM-CSF in the pathogenesis of asthma. GM-CSF messenger ribonucleic acid (mRNA) has been detected in BAL cells from asthmatics [16], and increased GM-CSF protein has been reported in the supernatant from cultured BAL cells [17], and bronchial epithelial cells [18], from asthmatics with moderate to severe disease. Also, increases in immunohistochemical staining for GM-CSF protein have been 
described in airway epithelial cells in airway biopsies from asthmatic compared to nonasthmatic subjects [19]. At the present time, no studies have directly investigated the relationships between GM-CSF protein in BAL cells or in bronchial tissue and the presence of activated eosinophils and methacholine airway hyperresponsiveness in mild asthmatics.

The purpose of this study was to compare the numbers of eosinophils, and the amounts of eosinophil-derived cationic protein (ECP), an indicator of eosinophil activation, and GM-CSF in the blood, BAL fluid, BAL cells and bronchial tissue of mild asthmatics and nonasthmatics. We hypothesized that eosinophil numbers would be increased in the asthmatic subjects. We also sought to examine whether the presence of GM-CSF protein was associated with eosinophil number and function. To evaluate the physiological significance of these markers of inflammation, we examined the relationships between eosinophil numbers, ECP and GM-CSF and methacholine airway responsiveness.

\section{Methods}

\section{Subjects}

Eight patients with mild asthma and 10 nonasthmatic subjects were selected for study (table 1). The study was approved by the Ethics Committee of McMaster University Medical Center and all subjects provided written informed consent. All asthmatics and five nonasthmatics were atopic, as indicated by one or more positive weal and flare responses to a battery of 16 skin-prick tests to common allergens. All subjects were nonsmokers, and none had experienced a respiratory infection during the 4 weeks prior to the study. The asthmatic subjects were stable at the time of study, requiring only intermittent use of inhaled $\beta_{2}$-agonists, and having baseline forced expiratory volume in one second $\left(\mathrm{FEV}_{1}\right)$ values $>70 \%$ predicted.

\section{Study design}

Subjects attended the laboratory on two occasions. At the initial visit, subjects completed a respiratory questionnaire and a full medical history, physical examination, skin-prick tests and an electrocardiogram (ECG) was performed. A blood sample was taken to measure white blood cell count, platelet count, prothrombin time and partial thromboplastin time. Baseline spirometry and a methacholine inhalation test were then performed. Within one week, subjects returned to the laboratory to complete a short follow-up questionnaire and perform spirometry. Providing the $\mathrm{FEV}_{1}$ was within $5-10 \%$ of the baseline value, fibreoptic bronchoscopy was performed. After bronchoscopy, subjects were observed until they had recovered from the procedure.

\section{Methacholine inhalation test}

To determine the degree of airway responsiveness, a methacholine inhalation challenge was performed, as described by CоскCROFT et al. [20]. Subjects inhaled doubling concentrations of methacholine chloride from a Wright nebulizer, for $2 \mathrm{~min}$ by tidal breathing. The test was continued until a fall in $\mathrm{FEV}_{1} \geq 20 \%$ of the baseline value occurred. The results were expressed as the provocative concentration causing a $20 \%$ fall in $\mathrm{FEV}_{1}$ $\left(\mathrm{PC}_{20}\right)$.

\section{Fibreoptic bronchoscopy}

Fibreoptic bronchoscopy was performed according to the recommendations of the National Institute of Health [21]. Subjects arrived at the research bronchoscopy suite at McMaster University Medical Center at 8:00 a.m., having fasted since midnight. An intravenous line was secured and blood samples obtained. Premedication with atropine (0.6 mg subcutaneous) was given $30 \mathrm{~min}$ prior

Table 1. - Subject characteristics

\begin{tabular}{|c|c|c|c|c|c|c|c|c|c|c|c|}
\hline \multicolumn{6}{|c|}{ Asthmatic } & \multicolumn{6}{|c|}{ Nonasthmatic } \\
\hline $\begin{array}{l}\text { Subject } \\
\text { No. }\end{array}$ & $\begin{array}{l}\text { Age } \\
\text { yrs }\end{array}$ & Sex & Atopy & $\begin{array}{l}\mathrm{FEV}_{1} \\
\% \text { pred }\end{array}$ & $\begin{array}{c}\mathrm{MCh} \mathrm{PC}_{20} \\
\mathrm{mg} \cdot \mathrm{ml}^{-1}\end{array}$ & $\begin{array}{l}\text { Subject } \\
\text { No. }\end{array}$ & $\begin{array}{l}\text { Age } \\
\text { yrs }\end{array}$ & Sex & Atopy & $\begin{array}{l}\mathrm{FEV}_{1} \\
\% \text { pred }\end{array}$ & $\begin{array}{c}\mathrm{MCh} \mathrm{PC}_{20} \\
\mathrm{mg} \cdot \mathrm{ml}^{-1}\end{array}$ \\
\hline 1 & 40 & M & + & 82 & 3.27 & 1 & 35 & $\mathrm{~F}$ & + & 111 & $>16$ \\
\hline 2 & 30 & $\mathrm{~F}$ & + & 86 & 1.56 & 2 & 31 & M & + & 99 & $>16$ \\
\hline 3 & 49 & $\mathrm{~F}$ & + & 90 & 1.00 & 3 & 41 & M & + & 108 & $>16$ \\
\hline 4 & 40 & $\mathrm{~F}$ & + & 98 & 1.28 & 4 & 27 & $\mathrm{~F}$ & + & 106 & $>16$ \\
\hline 5 & 21 & M & + & 100 & 13.40 & 5 & 29 & $\mathrm{~F}$ & + & 97 & $>16$ \\
\hline 6 & 42 & M & + & 108 & 2.20 & 6 & 31 & M & - & 110 & $>16$ \\
\hline 7 & 22 & $\mathrm{~F}$ & + & 93 & 2.20 & 7 & 35 & M & - & 96 & $>16$ \\
\hline \multirow[t]{3}{*}{8} & 25 & M & + & 89 & 1.45 & 8 & 44 & $\mathrm{~F}$ & - & 101 & $>16$ \\
\hline & & & & & & 9 & 28 & M & - & 92 & $>16$ \\
\hline & & & & & & 10 & 47 & $\mathrm{~F}$ & - & 97 & $>16$ \\
\hline Mean & 34 & & & 93 & $2.20 *$ & Mean & 35 & & & 101 & \\
\hline$\pm \mathrm{SD}$ & 11 & & & 8 & 1.33 & $\pm \mathrm{SD}$ & & & & 7 & \\
\hline
\end{tabular}

*: geometric mean and $\% \mathrm{SEM} . \mathrm{FEV}_{1}$ : forced expiratory volume in one second; $\mathrm{MCh}$ : methacholine; $\mathrm{PC}_{20}$ : provocative concentration producing a $20 \%$ fall in $\mathrm{FEV}_{1}$; $\mathrm{M}$ : male; $\mathrm{F}$ : female. 
to bronchoscopy. If sedation was required, midazolam $\left(0.07 \mathrm{mg} \cdot \mathrm{kg}^{-1}\right)$ was given intravenously. Asthmatic subjects inhaled $400 \mu \mathrm{g}$ of salbutamol, administered via a spacer device, before topical anaesthesia with lidocaine (Xylocaine) was applied to the upper airways. The bronchoscope (Olympus BF-1T20D; Olympus Optical Co., Tokyo, Japan) was inserted via a mouthpiece under further anaesthesia to suppress cough. During the entire procedure, oxygen at $4 \mathrm{l} \cdot \mathrm{min}^{-1}$ was administered via a nasal cannula and subjects were monitored with ECG and ear oximetry. No complications were observed in any subjects during or following bronchoscopy.

\section{Blood samples}

Two venous blood samples were obtained from each subject. Samples were collected in either ethylenediamine tetra-acetic acid (EDTA) -treated tubes, for total and differential white blood cell counts, or nontreated tubes, to obtain serum. Total cell counts were performed using a haemocytometer and differential cell counts were made using blood smears stained with a modified Wright-Geimsa (Diff-Quik Baxter, McGraw Park IL, USA). Duplicate cell counts (200 cells counted per slide) were performed by one investigator blinded to the subject tested. Cells were classified as neutrophils, eosinophils, lymphocytes, monocytes and basophils using standard morphological criteria. To obtain serum, venous blood was stored at room temperature for $2 \mathrm{~h}$, centrifuged twice $(1,350 \times \mathrm{g}$ for $10 \mathrm{~min})$ and then stored at $-70^{\circ} \mathrm{C}$.

\section{Biopsy samples}

Following insertion of the bronchoscope into the left lung, four mucosal biopsies were obtained from the lobar carinae and carinae of the basal segments, using separate forceps (FB-20C) for each biopsy. The position of the biopsy site and the appearance of the mucosal surface were carefully recorded. Two biopsies were placed immediately in glutaraldehyde for electron microscopy analysis, and one biopsy was fixed in $4 \%$ paraformaldehyde for future studies. The biopsy sample for immunohistochemistry was placed immediately in periodate -lysine-paraformaldehyde (PLP) fixative and stored at $4^{\circ} \mathrm{C}$ for $4 \mathrm{~h}$. The tissue was then transferred through four solutions (phosphate buffered saline (PBS), 10, 20 and $30 \%$ sucrose phosphate buffer), each for $4-6 \mathrm{~h}$ at $4^{\circ} \mathrm{C}$. The tissue was then frozen in Tissue-Tec OCT compound (Miles, Elkhart, In, USA) in $-70^{\circ} \mathrm{C}$ isopentane (Aldlich, Milwaukee, Wi, USA) and stored at $-70^{\circ} \mathrm{C}$. Serial cryostat sections $(6 \mu \mathrm{m})$ were cut onto slides coated with 3-aminopropyltriethoxysilane (Sigma, St. Louis, Mo, USA).

\section{Bronchoalveolar lavage}

The bronchoscope was subsequently inserted into the middle lobe of the right lung and wedged into a segment or subsegment. Five $20 \mathrm{ml}$ aliquots of prewarmed $\left(37^{\circ} \mathrm{C}\right)$, sterile normal saline were infused and gently aspirated back into polypropylene tubes kept on ice. The fluid was then centrifuged at $200 \times \mathrm{g}$ for $10 \mathrm{~min}$ at $4^{\circ} \mathrm{C}$. The supernatant was decanted and stored at $-70^{\circ} \mathrm{C}$. The cell pellet was washed in PBS and a total cell count was performed using a haemocytometer. The cells were then diluted with PBS to a concentration of $1 \times 10^{-6}$ cells $\cdot \mathrm{ml}^{-1}$. Cytocentrifuge slides were prepared and stained with a modified Wright-Geimsa (Diff-Quik, Baxter, McGraw Park, IL, USA) for a differential cell count (400 cells counted). Duplicate cell counts were performed by one investigator blinded to the subject tested. Cells were classified as macrophages, neutrophils, eosinophils and lymphocytes using standard morphological criteria. Total and differential cell counts were expressed as the number of cells per millilitre of fluid recovered. Cytocentrifuge slides prepared for immunocytochemistry were air dried for $5 \mathrm{~min}$, fixed in PLP for $10 \mathrm{~min}$ at $4^{\circ} \mathrm{C}$, placed in a $15 \%$ sucrose phosphate buffer solution for $10 \mathrm{~min}$ at $4^{\circ} \mathrm{C}$ and air dried overnight. Slides were then wrapped in pairs in foil and stored at $-70^{\circ} \mathrm{C}$.

\section{Tissue eosinophils}

Paraffin-embedded sections, prepared from the biopsy sample fixed in $4 \%$ paraformaldehyde, were stained with Chromotrope 2R (Sigma) to enumerate eosinophils in the tissue [22]. Slides were coded prior to evaluation. For each section, the number of positively staining cells within intact epithelium and along the length of the basement membrane to a depth of $115 \mu \mathrm{m}$ (delineated by a squared eyepiece graticule) was counted. A computerized and calibrated graphics tablet (Apple IIe) was used to determine the length of the epithelium and the area of the lamina propria in which counts were made. Results were expressed as the number of eosinophils per unit length of epithelium $(1 \mathrm{~mm})$ and area of lamina propria $\left(1 \mathrm{~mm}^{2}\right)$.

\section{Immunochemistry}

Immunochemistry was performed on BAL cytospins and tissue sections. To remove remaining OCT compound and sucrose and to enhance permeability and block nonspecific reactions, slides were incubated with Dulbecco's phosphate buffered saline (Gibco), supplemented with $0.01 \mathrm{M}$ hydroxyethylpiperazine ethanesulphonic acid (Hepes) buffer (Boehringer Mannheim Canada Ltd.) containing $0.1 \%$ saponin (Sigma) (DPBS $\mathrm{H}+\mathrm{S}$ ) for $5 \mathrm{~min}$ at room temperature, two times. To block nonspecific binding further, slides were incubated at room temperature with DPBS H $+\mathrm{S}$ containing $75 \%$ heat-inactivated human $\mathrm{AB}$ sera for $1 \mathrm{~h}$, and then with DPBS $\mathrm{H}+\mathrm{S}$ containing 25\% heat-inactivated normal rabbit serum (Zymed, San Francisco, Ca, USA) for $1 \mathrm{~h}$. Slides were washed briefly with DPBS $\mathrm{H}+\mathrm{S}$ before application of the monoclonal antibodies. The monoclonal antibodies used were EG2 (Pharmacia, Sweden), which recognizes the cleaved form of human ECP and is thought to represent eosinophil activation [23], and a mouse monoclonal antibody which reacts with human GM-CSF protein (Genzyme, Boston, Ma, USA). EG2 and GM-CSF antibodies were diluted in DPBS $\mathrm{H}+\mathrm{S}$ containing $0.1 \%$ bovine serum albumin (Zymed) at final concentrations of 1 and $3 \mu \mathrm{g} \cdot \mathrm{ml}^{-1}$, 
respectively. Slides were incubated overnight at $4^{\circ} \mathrm{C}$ and then washed in DPBS $\mathrm{H}+\mathrm{S}$. Labelling of the monoclonal antibodies was detected by the alkaline phosphatase anti-alkaline phosphatase method (APAAP Kit, Dako, Santa Barbara, Ca, USA). Slides were washed in distilled water, lightly counterstained with Mayer's haematoxylin (Sigma) and mounted. Appropriate system and specific controls were included in each assay.

\section{Immunochemistry quantification}

All slides were coded before evaluation. For BAL cytospins, the cell pellet was divided into four equal sections, delineated with a squared eyepiece graticule. At least 100 cells were counted in each section. Results were expressed as the percentage of positively stained cells. The intraclass correlation coefficient, a stringent test of reproducibility, for repeated counts was 0.99 for EG2 and 0.99 for repeated counts of GM-CSF. Assessment of staining for the biopsy specimens was performed with a semiquantitative method, previously described for evaluating immunohistochemical staining [24]. Briefly, two observers graded the extent and intensity of positive staining for each biopsy specimen on a scale from 1 (negative) to 5. Intraclass correlation coefficients between observers were 0.81 for EG2 and 0.92 for GM-CSF.

\section{ECP and GM-CSF assays}

Levels of ECP in serum and BAL fluid were determined using a double-antibody radioimmunoassay (Kabi Pharmacia Diagnostics AB, Sweden), with results expressed in $\mu \mathrm{g} \cdot l^{-1}$. Assay sensitivity for ECP was $2 \mu \mathrm{g} \cdot l^{-1}$. Measurement of GM-CSF in serum and 20 fold concentrated (Amicon-10, Amicon Corp., Danvers, Ma, USA) BAL fluid was performed using an enzyme-linked immunosorbent assay (Quantikine, Research and Diagnostics System, Minneapolis, Mn, USA), with results expressed in $\mathrm{pg} \cdot \mathrm{ml}^{-1}$. Assay sensitivity for GM-CSF was $2.8 \mathrm{pg} \mathrm{ml}^{-1}$ for serum and $1.5 \mathrm{pg} \cdot \mathrm{ml}^{-1}$ for BAL fluid. In all assays, samples were analysed in duplicate.

\section{Statistical analysis}

Statistical analyses were performed using the CSS Statistica computer software program. Data distributions were checked for normality using Kolmogorov-Smirnoff and Chi-squared analyses. As most distributions were significantly different from normal, nonparametric statistics were used. Given the a priori hypothesis that eosinophils would be increased in asthmatic compared to nonasthmatic subjects, one-tailed Mann-Whitney U-tests for unpaired samples were used for eosinophil counts. Differences in indices of eosinophil activation (ECP levels and EG2 staining) and GM-CSF between asthmatics and nonasthmatics were examined using twotailed Mann-Whitney U-tests. Spearman's rank correlation coefficient test (Rs) was used to examine the association between inflammatory parameters and the physiological measurement of airway responsiveness. A p-value of $<0.05$ was accepted as statistically significant.

\section{Results}

Eosinophils were increased in the blood, BAL and biopsy tissue from mild asthmatic subjects. The percentage of circulating eosinophils was significantly higher in the asthmatic subjects, with a median of $5 \%$ (range $3-13 \%)$, than in nonasthmatic subjects, with a median of $3 \%$ (range $1-9 \%)(\mathrm{p}<0.05)$. The absolute number of circulating eosinophils was also significantly higher in asthmatics, with a median of $36 \times 10^{4}$ cells $\cdot \mathrm{ml}^{-1}$ (range $16-100 \times 10^{4}$ cells $\cdot \mathrm{ml}^{-1}$ ), than in nonasthmatics, with a median of $17 \times 10^{4}$ cells $\cdot \mathrm{ml}^{-1}$ (range $6-52 \times 10^{4}$ cells $\cdot \mathrm{ml}^{-1}$ ) $(p<0.01)$. The percentage of BAL eosinophils was also significantly increased in asthmatic subjects, with a median value of $1.4 \%$ (range $0.0-5.0 \%$ ), compared to nonasthmatics, with a median of $0.5 \%$ (range $0.0-2.0 \%)(\mathrm{p}<0.05)$ (table 2).

In bronchial biopsy tissue, eosinophils were again significantly higher in asthmatic than nonasthmatic subjects (fig. 1). In areas of intact epithelium, intraepithelial eosinophils could be seen in asthmatics, with a median of 1.05 cells $\cdot \mathrm{mm}^{-1}$ (range $0.67-3.18$ cells $\cdot \mathrm{mm}^{-1}$ ) but were never observed in nonasthmatic subjects $(\mathrm{p}<0.01)$. Within the lamina propria, eosinophils were increased in asthmatics, with a median of 17.02 cells $\cdot \mathrm{mm}^{-2}$ (range 7.41-78.95 cells $\cdot \mathrm{mm}^{-2}$ ), compared to nonasthmatics, with a median of 1.41 cells $\cdot \mathrm{mm}^{-2}$ (range $0.00-10.81$ cells $\left.\cdot \mathrm{mm}^{-2}\right)(\mathrm{p}<0.01)$.

Immunocytochemistry on BAL cells demonstrated that asthmatics had a significantly increased number of cells positive for EG2 and GM-CSF (fig. 2). The median value of EG2-positive cells was $2.03 \%$ for asthmatics

Table 2. - Bronchoalveolar lavage cell counts

\begin{tabular}{|c|c|c|c|c|c|c|}
\hline $\begin{array}{l}\text { Sbt } \\
\text { No. }\end{array}$ & $\begin{array}{c}\text { Return } \\
\text { ml }\end{array}$ & $\begin{array}{c}\text { Total cells } \\
\times 10^{4} \cdot \mathrm{ml}^{-1}\end{array}$ & $\begin{array}{c}\mathrm{Mac} \\
\%\end{array}$ & $\begin{array}{c}\mathrm{Neu} \\
\%\end{array}$ & $\begin{array}{c}\text { Lym } \\
\%\end{array}$ & $\begin{array}{c}\text { Eos } \\
\%\end{array}$ \\
\hline \multicolumn{7}{|c|}{ Asthmatic subjects } \\
\hline 1 & 55 & 5.59 & 92.0 & 1.8 & 4.8 & 1.5 \\
\hline 2 & 66 & 8.35 & 95.0 & 0.0 & 3.5 & 1.3 \\
\hline 3 & 49 & 3.88 & 92.0 & 1.0 & 2.0 & 5.0 \\
\hline 4 & 67 & 4.85 & 95.5 & 2.5 & 2.0 & 0.0 \\
\hline 5 & 55 & 9.09 & 95.3 & 1.0 & 2.5 & 1.3 \\
\hline 6 & 57 & 1.39 & 94.5 & 2.5 & 0.8 & 2.3 \\
\hline 7 & 69 & 2.87 & 93.5 & 4.3 & 1.5 & 0.8 \\
\hline 8 & 67 & 7.99 & 85.3 & 1.0 & 12.3 & 1.5 \\
\hline Median & 62 & 5.22 & 94.0 & 1.4 & 2.3 & 1.4 \\
\hline \multicolumn{7}{|c|}{ Nonasthmatic subjects } \\
\hline 1 & 65 & 4.23 & 89.0 & 10.3 & 0.3 & 0.5 \\
\hline 2 & 47 & 3.15 & 89.0 & 6.5 & 3.5 & 1.0 \\
\hline 3 & 62 & 8.61 & 97.3 & 0.0 & 0.8 & 2.0 \\
\hline 4 & 65 & 4.42 & 93.3 & 2.3 & 4.5 & 0.0 \\
\hline 5 & 62 & 9.64 & 93.0 & 3.3 & 2.3 & 1.5 \\
\hline 6 & 68 & 13.16 & 87.0 & 7.8 & 5.0 & 0.3 \\
\hline 7 & 67 & 23.06 & 97.3 & 1.8 & 1.0 & 0.0 \\
\hline 8 & 51 & 6.72 & 94.0 & 1.8 & 4.3 & 0.0 \\
\hline 9 & 71 & 11.83 & 98.3 & 0.3 & 0.5 & 1.0 \\
\hline 10 & 76 & 9.70 & 94.8 & 2.5 & 2.3 & 0.5 \\
\hline Median & 65 & 9.13 & 93.7 & 2.4 & 2.3 & 0.5 \\
\hline p-value* & 0.59 & 0.08 & 0.86 & 0.27 & 0.59 & 0.03 \\
\hline
\end{tabular}

Mac: macrophage; Neu: neutrophil; Lym: lymphocyte; Eos: eosinophil; Sbt: subject. *: p-value for comparison between asthmatics and nonasthmatics. 
a)

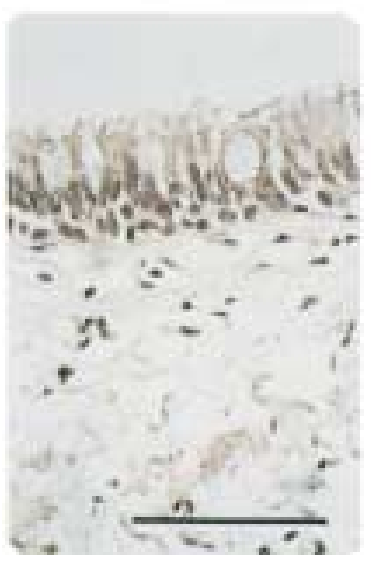

b)

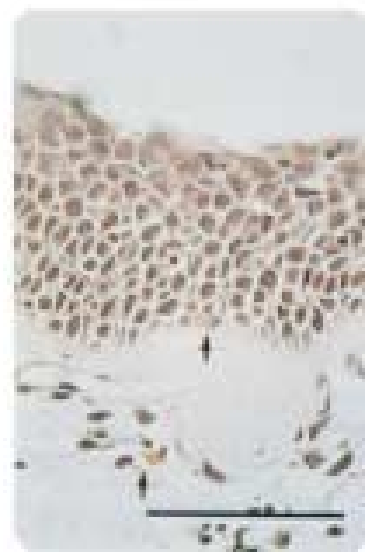

Fig. 1. - Staining for chromotrope $2 \mathrm{R}$ within bronchial biopsy tissue from: a) a nonasthmatic subject; and b) an asthmatic subject. Asthmatic subjects had significantly increased numbers of eosinophils in the epithelium and lamina propria compared to nonasthmatic subjects. Arrows indicate positively (red) stained eosinophils seen in the lamina propria and within the epithelium of the asthmatic tissue. (Scale bar=50 $\mu \mathrm{m})$.

and $0.10 \%$ for nonasthmatics $(\mathrm{p}<0.01)$. The median value of GM-CSF-positive cells was $36 \%$ for asthmatics and $0 \%$ for nonasthmatics $(\mathrm{p}<0.05)$. In BAL cells from asthmatics, staining for EG2 was present in the cytoplasm and was also observed external to the cell surface, suggestive of ECP secretion (fig. 3). Occasionally, staining for EG2 was apparent in alveolar macrophages, suggesting engulfment of secreted ECP. Staining for GMCSF in asthmatic BAL cells was evident in the cytoplasm of a variety of cell types which, based on size and morphology, resembled eosinophils, alveolar macrophages and lymphocytes (fig. 4). In nonasthmatics, few BAL cells were positive for either EG2 or GM-CSF. No staining was present in the slides stained with immunoglobulin $\mathrm{G}_{1}\left(\mathrm{IgG}_{1}\right)$ (negative control).

a) EG2 +ve cells \%

$$
\left.\begin{array}{l}
6 \\
5- \\
4- \\
3- \\
2- \\
1- \\
0
\end{array}\right]
$$

b) GM-CSF +ve cells \%

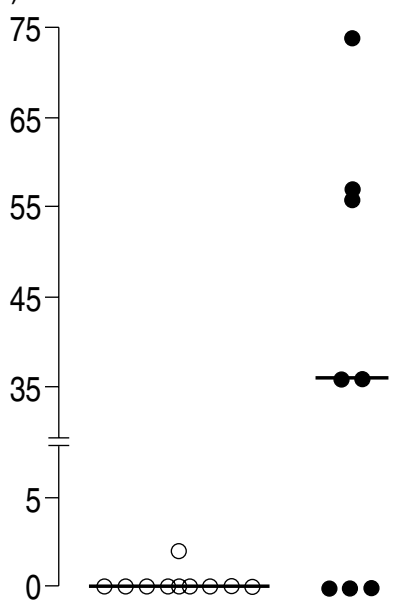

Fig. 2. - Percentage of BAL cells positive for: a) EG2; and b) GMCSF in nonasthmatic ( $\bigcirc$ ) and asthmatic ( $)$ subjects. Asthmatic subjects had significantly increased numbers of BAL cells positive for EG2 and GM-CSF, compared to nonasthmatic subjects. Bars indicate median values. BAL: bronchoalveolar lavage; GM-CSF: granulocyte-macrophage colony-stimulating factor.

a)

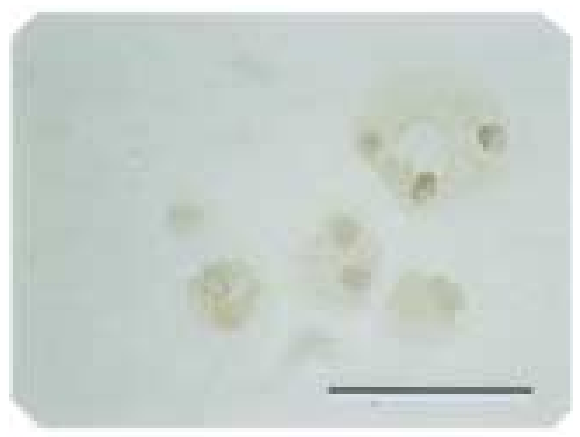

b)

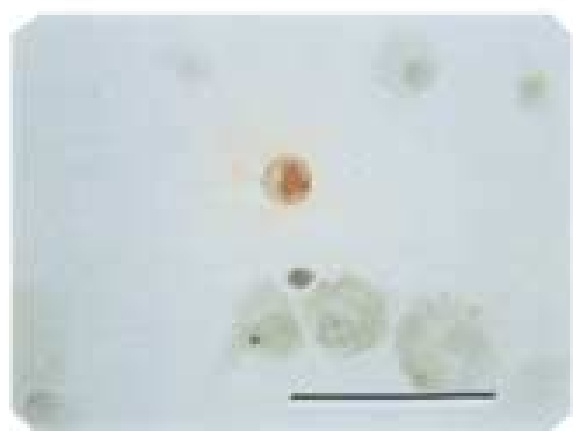

Fig. 3. - Immunocytochemistry with EG2 in bronchoalveolar lavage (BAL) cells from: a) a nonasthmatic subject; and b) an asthmatic subject. Staining is not evident in cells from the nonasthmatic subject. Positive (red) staining with EG2 is seen in the cytoplasm, with fainter staining also seen surrounding the eosinophil from an asthmatic subject. (Scale bar $=50 \mu \mathrm{m})$.

a)

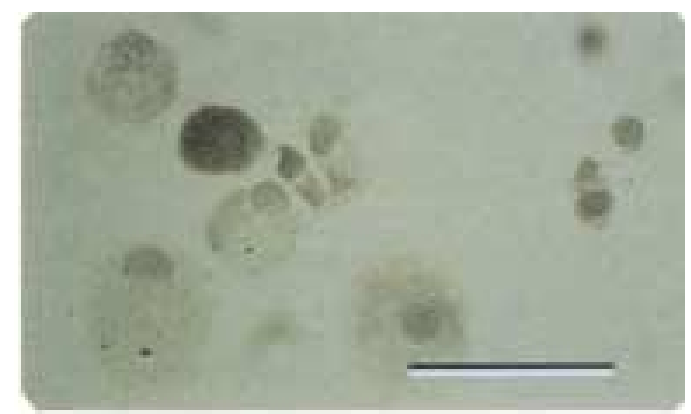

b)

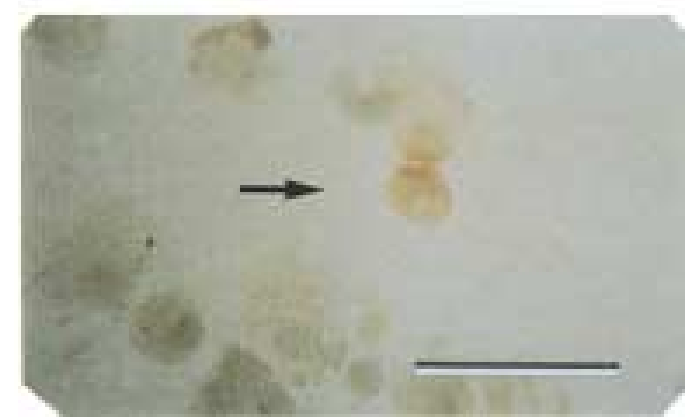

Fig. 4. - Immunocytochemistry for GM-CSF in BAL cells from: a) nonasthmatic subject; and b) asthmatic subject. In cells from the nonasthmatic subject, no staining is evident. In BAL cells from the asthmatic subject, positive (red) staining for GM-CSF is seen in the cytoplasm of a cell which, based on morphology, appears to be an eosinophil (Arrow). (Scale bar=50 $\mu \mathrm{m})$. 
a) EG2 staining

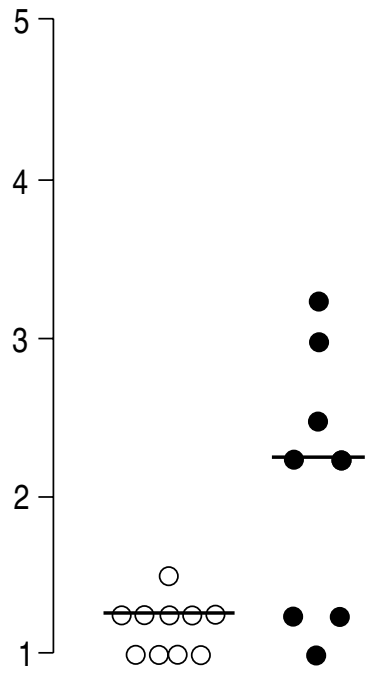

b) GM-CSF staining

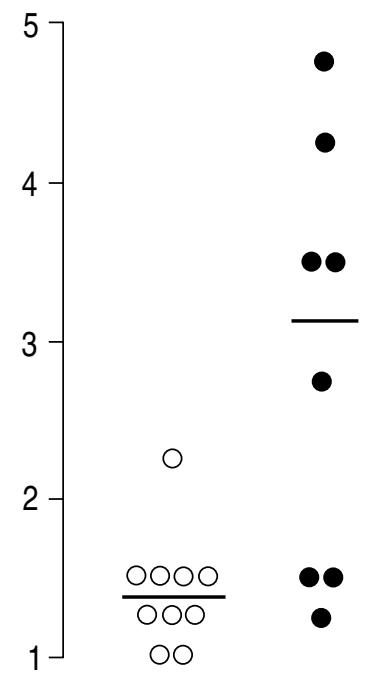

Fig. 5. - Staining of biopsy tissue for: a) EG2 and; b) GM-CSF in nonasthmatic $(\bigcirc)$ and asthmatic $(O)$ subjects. Biopsy tissue from asthmatic subjects exhibited significantly greater staining for EG2 and GM-CSF, compared to nonasthmatic subjects. Bars indicate median values. Two observers graded the extent and intensity of positive staining for each biopsy specimen on a scale from 1 (negative) to 5 [24]. For abbreviations see legend to figure 2 .

a)

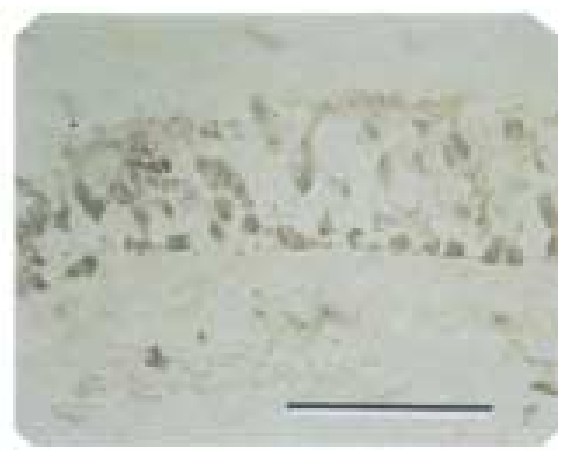

b)

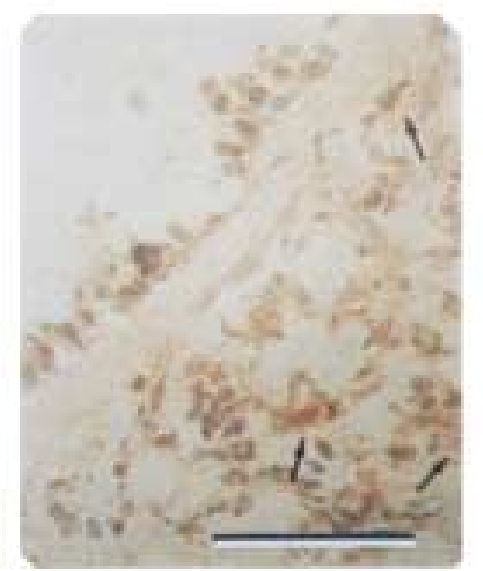

Fig. 6. - Immunohistochemistry for EG2 on bronchial biopsy tissue from: a) nonasthmatic subject; and b) an asthmatic subject. No staining is evident in tissue from the nonasthmatic subject. In the asthmatic tissue, arrows indicate intra- and extracellular positive (red) staining for EG2. (Scale bar=50 $\mu \mathrm{m})$. a)

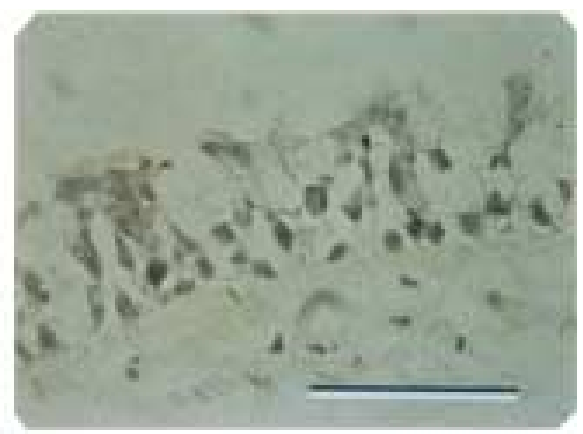

b)

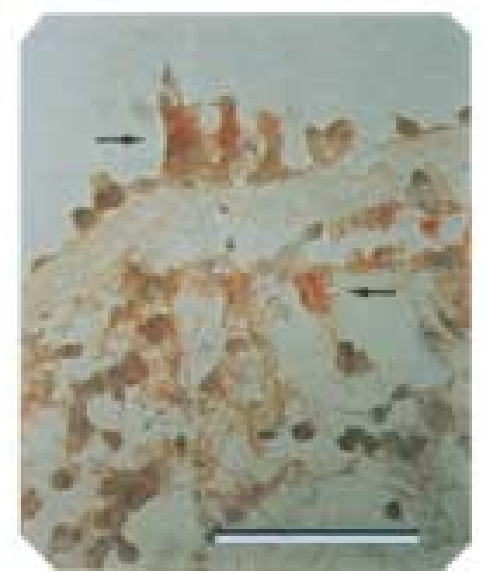

Fig. 7. - Immunohistochemistry for GM-CSF on bronchial biopsy tissue from: a) a nonasthmatic subject; and b) an asthmatic subject. No staining is evident in tissue from the nonasthmatic subject. In the asthmatic tissue, arrows indicate positive (red) staining for GM-CSF in the lamina propria and epithelium. GM-CSF: granulocyte-macrophage colony-stimulating factor. (Scale bar=50 $\mu \mathrm{m}$ ).

Immunohistochemistry on biopsy tissue demonstrated that asthmatics had significantly increased staining for EG2 and GM-CSF (fig. 5). The median value of EG2 staining was 2.25 for asthmatics and 1.25 for nonasthmatics $(\mathrm{p}<0.05)$. For GM-CSF staining, the median value was 3.13 for asthmatics and 1.38 for nonasthmatics $(\mathrm{p}<0.05)$. In asthmatic tissue, staining for EG2 was mainly intracellular and, although localized mainly beneath the basement membrane, intraepithelial EG2-positive cells were observed in some asthmatics (fig. 6). Intra- and extracellular staining was observed for GM-CSF in asthmatic tissue, and was apparent both in the lamina propria and epithelium (fig. 7). No staining was present in the negative control slides.

In the serum and BAL supernatant, median concentrations of ECP and GM-CSF were not significantly higher in asthmatic compared to nonasthmatic subjects (table 3 ). No significant differences were found in any of the measurements between atopic nonasthmatics and nonatopic nonasthmatics. However, this may reflect the small sample size $(n=5)$ of each group.

The associations between staining for GM-CSF in lavage cells and biopsy tissue and eosinophil number and activation were examined. The percentage of BAL cells positive for GM-CSF was significantly correlated to EG2 staining in biopsy tissue $(\mathrm{Rs}=0.59 ; \mathrm{p}<0.05)$. Staining for GM-CSF in biopsy tissue was significantly correlated to the percentage of BAL eosinophils $(\mathrm{Rs}=0.53$; $\mathrm{p}<0.05)$ 
Table 3. - Serum and BAL supernatant concentrations of ECP and GM-CSF in asthmatics and nonasthmatics

\begin{tabular}{lccc}
\hline & Asthmatics & Nonasthmatics & $\mathrm{p}$ \\
\hline Serum & 10.3 & 9.3 & 0.6 \\
$\quad$ ECP $\mu \mathrm{g} \cdot l^{-1}$ & $(5.1-45.5)$ & $(1.7-32.8)$ & \\
& 16.9 & 10.0 & 0.4 \\
GM-CSF $\mathrm{pg} \cdot \mathrm{ml}^{-1}$ & $(6.3-38.2)$ & $(2.6-35.2)$ & \\
& & & \\
BAL & 4.1 & 3.4 & \\
$\quad$ ECP $\mu \mathrm{g} \cdot l^{-1}$ & $(1.3-16.2)$ & $(1.3-9.7)$ & 0.8 \\
& 13.7 & 10.0 & 0.6 \\
GM-CSF $\mathrm{pg} \cdot \mathrm{ml}^{-1}$ & $(8.0-25.1)$ & $(2.5-33.3)$ & \\
\hline
\end{tabular}

Median with range in parentheses. BAL: bronchoalveolar lavage; ECP: eosinophil cationic protein; GM-CSF: granulocyte-macrophage colony-stimulating factor.

and the number of eosinophils in the epithelium ( $\mathrm{Rs}=0.68$; $\mathrm{p}<0.05)$ and the lamina propria $(\mathrm{Rs}=0.59 ; \mathrm{p}<0.05)$

The associations between methacholine (MCh) airway responsiveness and eosinophil numbers and activation, as well as GM-CSF were examined. Significant correlations were found between $\mathrm{MCh} \mathrm{PC}_{20}$ and the number of circulating eosinophils ( $R s=-0.53 ; \mathrm{p}<0.05)$, the number of eosinophils in the epithelium ( $R s=-0.95 ; p<0.001)$ and the number of eosinophils in the lamina propria $(\mathrm{Rs}=$ $-0.71 ; \mathrm{p}<0.001)$. Significant correlations were also observed between $\mathrm{MCh} \mathrm{PC}_{20}$ and staining for EG2 in BAL cells $(\mathrm{Rs}=-0.48 ; \mathrm{p}<0.05)$ and biopsy tissue $(\mathrm{Rs}=-0.65 ; \mathrm{p}<0.01)$. Staining for GM-CSF in BAL cells was also significantly correlated with $\mathrm{MCh} \mathrm{PC}_{20}(\mathrm{Rs}=-0.81 ; \mathrm{p}<0.001)$, and a strong trend was evident between $\mathrm{MCh}^{\mathrm{PC}} \mathrm{C}_{20}$ and GMCSF staining in biopsy tissue $(\mathrm{Rs}=-0.46 ; \mathrm{p}=0.056)$.

\section{Discussion}

This study demonstrates that stable asthmatic subjects with mildly increased airway hyperresponsiveness have ongoing airway inflammation, as indicated by increased numbers of activated eosinophils in BAL and biopsies and increases in the eosinophil regulatory cytokine, GM-CSF. We found relationships between the number and function of eosinophils and GM-CSF and, furthermore, these markers of airway inflammation were related to airway function, based on the measurement of airway responsiveness. These findings imply that the eosinophil contributes to ongoing airway inflammation, even in mild asthma, and that airway hyperresponsiveness may be a consequence of eosinophilic inflammation.

A proinflammatory role for the eosinophil in asthma is suggested by the increased presence and activation of eosinophils in asthmatics. We found an increased number of eosinophils in the blood, bronchoalveolar lavage and biopsy tissue of the mild asthmatics studied. Peripheral blood eosinophilia, observed in asthmatics since the turn of the century [25], has been confirmed in later studies $[5,26]$. Subsequent investigations, using bronchoalve- olar lavage to sample the airway lumen, have documented a significant increase in eosinophils in asthmatic airways [7, 27], but this finding has not been universal [9]. Most recently, eosinophil numbers have been investigated in asthmatic and nonasthmatic bronchial biopsy tissue, with an increase [8], or no difference [10], reported in asthmatic tissue. The sometimes inconsistent increase in eosinophil numbers in BAL and biopsy samples in asthmatics may reflect the mild state of disease in the subjects studied.

Within the airways, eosinophil activation may be of greater importance than eosinophil number [28]. Based on detection of the secreted form of ECP with EG2 antibody, we found an increased number of activated eosinophils in the bronchoalveolar lavage cells and biopsy tissue of mild asthmatics. Increased EG2-positive lavage cells in asthmatics compared to nonasthmatics is a novel finding. This result implies that eosinophils within the bronchial lumen may continue to secrete ECP, potentially causing damage to pulmonary epithelial cells. In contrast to some investigators $[29,30]$, we were not able to detect significant differences in the concentration of ECP in lavage fluid between asthmatics and nonasthmatics. However, higher local concentrations of ECP within asthmatic airways may have existed due to the increased number of activated BAL eosinophils. Such a difference may not have been detected due to dilution effects from the lavage instillate. Confirming findings from recent studies $[8,12,26]$, we found increases in the secreted form of ECP in asthmatic biopsy tissue. Our findings demonstrate, for the first time, that eosinophils both in BAL and biopsy tissue are activated in mild asthmatics. As these sites presumably sample both peripheral and central airways, our results imply that eosinophil activation occurs throughout asthmatic airways.

The increased presence of GM-CSF protein in asthmatic lavage cells and biopsy tissue supports the findings of Sousa et al. [19], who described GM-CSF immunostaining in asthmatic airway epithelium, and provides evidence for the involvement of this cytokine in asthma airway inflammation. Detection of GM-CSF protein in lavage cells extends previous findings of lavage cells positive for GM-CSF mRNA [16]. Our findings imply that mRNA translation occurs, enabling the protein to exert its biological activities in asthmatic airways. In agreement with mRNA findings, we observed GM-CSF within cells which, based on size and morphology, included eosinophils, lymphocytes and macrophages. The presence of GM-CSF protein within eosinophils is of particular significance, suggesting the possibility of autocrine regulation of eosinophil function [31]. Detection of GM-CSF protein within the airway mucosa and epithelium also points toward the involvement of GM-CSF in the local regulation of airway inflammation. In contrast to the observations of BROwN et al. [32], we could not demonstrate a significant increase in GM-CSF in blood in the asthmatics in this study. This probably reflects the fact that the asthmatics in our study were mild and stable at the time of study, whilst BROwn et al. [32] studied patients undergoing acute asthma. 
The relationships between GM-CSF and eosinophil number and function observed in the present study provide some validation for results from in vitro studies documenting GM-CSF regulation of eosinophils. The correlation between the presence of GM-CSF in biopsy tissue and eosinophils in BAL and biopsy tissue suggests that GM-CSF could be involved in the recruitment and/or survival of airway eosinophils. This suggestion is supported by in vitro studies, which have shown GM-CSF to be chemotactic for eosinophils [13], and to prolong their survival [15]. The correlations between the presence of GM-CSF in lavage cells and EG2 staining in biopsy tissue suggests that GM-CSF may contribute to activation of eosinophils within airway tissue. In vitro studies have clearly shown that GM-CSF can enhance the release of inflammatory mediators from eosinophils [15]. Importantly, however, these correlations do not imply cause and effect. One alternative explanation for our findings could be that a common mechanism coregulates eosinophil activation and GM-CSF production. Recently, several investigators have attributed such an "orchestrating" role to the T-lymphocyte [33, 34]. Another reason for the relationship that we observed between GM-CSF and eosinophils may relate to eosinophil autocrine regulation. It is conceivable that the continued production of GM-CSF by eosinophils, with their subsequent activation, would lead to a self-perpetuating inflammatory process [28]. This autocrine mechanism could be an important mechanism in the chronicity of asthma airway inflammation, even in subjects with mild disease.

The physiological importance of increases in eosinophil number and function and GM-CSF in asthmatics is highlighted by the significant relationships that we observed between these inflammatory markers and airway responsiveness. These findings support the involvement of the eosinophil, potentially activated by GM-CSF, in mediating the airway hyperresponsiveness associated with asthma. It is quite likely, however, that other cells and other cytokines, such as interleukin-3 and -5 (IL-3 and IL-5), contribute to the pathophysiology of asthma. Examination of individual subject values for the numerous inflammatory markers that have been investigated in other studies [8, 12, 26, 33], highlights the remarkable variability observed in asthmatic subjects. In our own study, a wide range of values were observed for GM-CSF and eosinophil number and function (figs. 2 and 5; table 2). This variability points toward the presumably complex and multifactorial aetiology of asthma.

In summary, we have found that mild asthmatics demonstrate increases in eosinophils, eosinophil cationic protein and GM-CSF protein compared to nonasthmatics. Relationships were evident between GM-CSF and eosinophil number and function and, furthermore, these inflammatory markers were related to airway responsiveness. These findings imply that the eosinophil and GM-CSF, a cytokine regulating eosinophil function, play an important role in the chronic airway inflammation and airway hyperresponsiveness evident even in mild asthma.

\section{References}

1. O'Byrne PM. In: O'Byrne PM ed, asthma as an inflammatory disease. New York, Marcel Dekker Inc, 1990; 143-158

2. Weller PF, Lee CW, Foster DW, Corey EJ, Austen KF, Lewis RA. Generation and metabolism of 5-lipoxygenase pathway leukotrienes by human eosinophils: predominant production of leukotriene $\mathrm{C}_{4}$. Proc Natl Acad Sci USA 1983; 80: 7626-7630.

3. Ayers GH, Altman LC, Gleich GJ, Loegering DA, Baker CB. Eosinophil- and eosinophil granule-mediated pneumocyte injury. J Allergy Clin Immunol 1985; 76: 595604.

4. Gundel RH, Letts LG, Gleich GJ. Human eosinophil major basic protein induces airway constriction and airway hyperresponsiveness in primates. J Clin Invest 1991; 87: 1470-1473.

5. Durham SR, Loegering DA, Dunnette S, Gleich GJ, Kay AB. Blood eosinophils and eosinophil-derived proteins in allergic asthma. J Allergy Clin Immunol 1989; 84: 931-936.

6. Gibson PG, Girgis-Gabardo A, Morris MM, et al. Cellular characteristics of sputum from patients with asthma and chronic bronchitis. Thorax 1989; 44: 693-699.

7. Kirby JG, Hargreave FE, Gleich GJ, O'Byrne PM. Bronchoalveolar cell profiles of asthmatic and nonasthmatic subjects. Am Rev Respir Dis 1987; 136: 379383.

8. Azzawi M, Bradley B, Jeffery PK, et al. Identification of activated T-lymphocytes and eosinophils in bronchial biopsies in stable atopic asthma. Am Rev Respir Dis 1990; 142: 1407-1413.

9. Beasley R, Roche WR, Roberts JA, Holgate ST. Cellular events in the bronchi in mild asthma and after bronchial provocation. Am Rev Respir Dis 1989; 139: 806-817.

10. Jeffery PK, Wardlaw AJ, Nelson FC, Collins JV, Kay AB. Bronchial biopsies in asthma. Am Rev Respir Dis 1989; 140: 1745-1753.

11. Lozewicz S, Gomez E, Ferguson H, Davies RJ. Inflammatory cells in the airways in mild asthma. $\mathrm{Br}$ Med J 1988; 297: 1515-1516.

12. Djukanovic R, Wilson JW, Britten KM, et al. Quantitation of mast cells and eosinophils in the bronchial mucosa of symptomatic atopic asthmatics and healthy control subjects using immunohistochemistry. Am Rev Respir Dis 1990; 142: 863-871.

13. Warringa RAJ, Mengelers HJJ, Kuijper PHM, Raaijmakers JAM, Bruijnzeel PLB, Koenderman L. In vivo priming of platelet-activating factor-induced eosinophil chemotaxis in allergic asthmatic individuals. Blood 1992; 79(7): 1836-1841.

14. Lopez AF, Williamson DJ, Gamble JR, et al. Recombinant human granulocyte-macrophage colony-stimulating factor stimulates in vitro mature human neutrophil and eosinophil function, surface receptor expression and survival. J Clin Invest 1986; 78: 1220-1228.

15. Owen WF, Rothenberg ME, Silberstein DS, et al. Regulation of human eosinophil viability, density and function by granulocyte/macrophage colony-stimulating factor in the presence of 3T3 fibroblasts. J Exp Med 1987; 166: 129-141.

16. Broide DH, Paine MM, Firestein GS. Eosinophils express interleukin-5 and granulocyte-macrophage colony-stimulating factor mRNA at sites of allergic inflammation in asthmatics. J Clin Invest 1992; 90: 1414-1424. 
17. Rotondetto $\mathrm{S}$, Prior $\mathrm{C}$, Ott $\mathrm{G}$, et al. In vitro relevant allergen exposure augments specific cytokine release from bronchoalveolar (BAL) cells in atopic asthma. Am Rev Respir Dis 1993; 147: A785. (Abstract).

18. Mattoli S, Marini M, Fasoli A. Expression of the potent inflammatory cytokines, GM-CSF, IL-6 and IL-8 in bronchial epithelial cells of asthmatic patients. Chest 1992; 101(3): 27S-29S.

19. Sousa AR, Poston RN, Lane SJ, Nakhosteen JA, Lee TH. Detection of GM-CSF in asthmatic bronchial epithelium and decrease by inhaled corticosteroids. Am Rev Respir Dis 1993; 147: 1557-1561.

20. Cockcroft DW, Murdock KY, Kirby J, Hargreave F. Prediction of airway responsiveness to allergen from skin sensitivity to allergen and airway responsiveness to histamine. Am Rev Respir Dis 1987; 135: 264-268.

21. Workshop Committee. Summary and recommendations of a workshop on the investigative use of fiberoptic bronchoscopy and bronchoalveolar lavage in asthmatics. $\mathrm{Am}$ Rev Respir Dis 1985; 132: 180-182.

22. Lendrum AC. A stain for eosinophil cells. J Pathol Bacteriol 1944; 56: 441-444.

23. Tai PC, Spry CJF, Peterson C, Venge P, Olsson I. Monoclonal antibodies distinguish between storage and secreted forms of eosinophil cationic protein. Nature 1984; 309: 182-184.

24. Leung DYM, Kurt-Jones E, Newburger JW, Cotran RS, Burns JC, Pober JS. Endothelial cell activation and high interleukin-1 secretion in the pathogenesis of acute Kawasaki disease. Lancet 1989; ii: 1298-1302.

25. Ellis AG. The pathological anatomy of bronchial asthma. Am J Med Sci 1908; 136: 407-429.
26. Bousquet J, Chanez P, Lacoste JY, et al. Eosinophilic inflammation in asthma. $N$ Engl J Med 1990; 323: 1033-1039.

27. Adelroth E, Rosenhall L, Johansson SA, Linden M, Venge P. Inflammatory cells and eosinophilic activity in asthmatics investigated by bronchoalveolar lavage. Am Rev Respir Dis 1990; 142: 91-99.

28. Busse WW, Calhoun WF, Sedgwick JD. Mechanism of airway inflammation in asthma. Am Rev Respir Dis 1993; 147: S20-S24.

29. Broide DH, Lotz M, Cuomo AJ, Coburn DA, Federman EC, Wasserman SI. Cytokines in symptomatic asthma airways. J Allergy Clin Immunol 1992; 89: 958-967.

30. Bousquet J, Chanez P, Lacoste JY, et al. Indirect evidence of bronchial inflammation assessed by titration of inflammatory mediators in BAL fluid of patients with asthma. J Allergy Clin Immunol 1991; 88: 649-660.

31. Moqbel R, Hamid Q, Ying S, et al. Expression of mRNA and immunoreactivity for the granulocyte/macrophage colony-stimulating factor in activated human eosinophils. J Exp Med 1991; 174: 749-752.

32. Brown PH, Crompton GK, Greening AP. Proinflammatory cytokines in acute asthma. Lancet 1991; 338: 590-593.

33. Bentley AM, Menz 9G, Storz C, et al. Identification of T-lymphocytes, macrophages and activated eosinophils in the bronchial mucosa in intrinsic asthma. Am Rev Respir Dis 1992; 146: 500-506.

34. Robinson DS, Bentley AM, Hartnell A, Kay AB, Durham SR. Activated memory T-helper cells in bronchoalveolar lavage fluid from patients with atopic asthma: relation to asthma symptoms, lung function and bronchial responsiveness. Thorax 1993; 48: 26-32. 